\title{
COVID-19 Outpatient Screening: A Novel Risk Score to Early Predict Admission in Isolation Care Units
}

\author{
Maroua Trigui ${ }^{1}$, Houda Ben Ayed ${ }^{2}$, Mondher Kassis ${ }^{1}$, Maissa Ben Jmaa ${ }^{2}$, Mariem Ben Hmida ${ }^{1}$, Hanen Maamri ${ }^{1}$, \\ Nouha Ketata ${ }^{2}$, Jihene Jedidi ${ }^{1}$, Sourour Yaich ${ }^{1}$, Habib Feki ${ }^{2}$, Jamel Damak ${ }^{1}$
}

\begin{abstract}
${ }^{1}$ Community Health and Epidemiology Department, Hedi Chaker University Hospital, University of Sfax, TUNISIA
${ }^{2}$ Preventive Medicine and Hospital Hygiene Department, Hedi Chaker University Hospital, Sfax, TUNISIA

${ }^{\star}$ Corresponding Author: drhoudabayed@gmail.com
\end{abstract}

Citation: Trigui M, Ben Ayed H, Kassis M, Ben Jmaa M, Ben Hmida M, Maamri H, Ketata N, Jedidi J, Yaich S, Feki H, Damak J. CovID-19 Outpatient Screening: A Novel Risk Score to Early Predict Admission in Isolation Care Units. Electron J Gen Med. 2021;18(5):em309. https://doi.org/10.29333/ejgm/11063

\section{ARTICLE INFO}

Received: 27 Mar. 2021

Accepted: 23 Jun. 2021

\begin{abstract}
The coronavirus disease in 2019 (COVID-19) pandemic is the defining global health crisis of our time. Delays in hospitalization of patients with a severe form of COVID-19 contribute to increased morbidity and mortality. This study aimed to perform a reliable and easy-to-use risk scoring system to early predict admission in COVID-19 isolation care units. It was a prospective study including all patients, consulting to the COVID-19 sorting box at Hedi Chaker university hospital, and who were clinically suspected COVID-19 during the first epidemic wave between March and June 2020. Of all,388 patients were enrolled in the study.Multivariate analysis showed that factors independently associated with admission to COVID-19 isolation tertiary-care unit were oxygen saturation $<88 \%$ (Adjusted Relative Risk (ARR) $=16.91 ; \mathrm{p}=0.013$ ), hypotension ( $A R R=11.71 ; \mathrm{p}=0.004$ ), oxygen saturation between 88 and $92 \%(A R R=5.90 ; p=0.001)$,respiratory wrestling signs ( $A R R=4.63 ; p=0.042$ ), dyspnea $(A R R=3.22 ; p<0.001)$, chronic hypertension (ARR=2.76; $p=0.027)$ and ischemic heart diseases $(A R R=2.67 ; p=0.035)$. The score had an AUROC of 0.75.At a cut-off point $\geq 2$, the scoring system had a sensitivity of $82.7 \%$, a specificity of $53.8 \%$, a positive predictive value of $53 \%$ and a negative predictive value $83.1 \%$. When the cut-off was raised to 3 , the sensitivity dropped (44\%) and the specificity increased appreciably (92.9\%).
\end{abstract}

Keywords: COVID-19, hospitalization, screening

\section{INTRODUCTION}

In December 2019, a newly identified virus spread throughout China and has rapidly extend worldwide causing a major public health crisis in the six continents [1]. This pathogen belongs to the Coronaviridae family of viruses and was designed as "Severe Acute Respiratory Syndrome Coronavirus 2" (SARS-CoV-2) by the Coronaviridae Study Group of the International Committee on Taxonomy of Viruses [2]. The disease itself was termed coronavirus disease in 2019 (COVID19) by the World Health Organization [3]. After the SARS-CoV and the Middle East respiratory syndrome MERS-CoV, SARSCoV-2 caused the third coronavirus outbreak in last 20 years [4]. Human coronaviruses mainly target the human respiratory system [5]. In fact, COVID-19 encompassed different clinical representations of emerging acute respiratory infection ranging from asymptomatic infection or mild upper respiratory disease to acute respiratory distress syndrome with multiple organ failure representing a clinical challenge for physicians $[6,7]$. The first confirmed case of COVID-19 in Tunisia was reported on 2 March 2020 [8]. The strategy of the country was to screen on suspects and their entourage [9]. However, the very limited screening capacity has resulted in undetected cases of infection and increased mortality [10]. Besides, delays in hospitalization of patients with a severe form of COVID-19 contribute to increased morbidity and mortality [11]. Therefore, an early warning model is needed to predict the risk of hospitalization of COVID-19 patients and thereby to improve the prognosis [6]. In light of this, this study aimed to perform a reliable and easy-to-use risk scoring system to early predict admission in COVID-19 isolation care units.

\section{MATERIALS AND METHODS}

\section{Study Design and Settings}

This was a prospective study including all patients, consulting to the COVID-19 sorting box at Hedi Chaker university hospital, and who were clinically suspected COVID19 during the first epidemic wave between March and June 2020. This sorting box was the only COVID-19 triage center in Sfax and it received all patients from both private or public sectors. All cases were diagnosed in the triage center and then notified to the regional directorate of health.

\section{Inclusion Criteria and Case Definitions}

Patients were sorted on the basis of a score established according to the Tunisian national guidelines, including exposure with close contact; fever; cough or dyspnea; sore 
throat; nausea, vomiting or diarrhea; chronic renal, cardiac or respiratory failure [12]. Firstly, patients who had a score $\geq 4$ at the COVID-19 pre-sorting box $(n=862)$ were initially included in the study. Secondly, they were clinically reassessed in the COVID-19 sorting box, of whom only 505 patients were selected as suspected cases. Then, on the basis of expert physician judgment and further investigations, patients who had another diagnosis explaining the observed clinical characteristics were finally excluded ( $n=117)$. A total of 388 subjects were enrolled in this survey. The decision to hospitalize patients in the COVID19 isolation tertiary-care unit was made on the basis of clinical evaluation. Hypotension was defined as a systolic blood pressure $<90 \mathrm{mmHg}$ or/ and diastolic blood pressure $<60$ $\mathrm{mmHg}$. Hypertension was defined as a systolic blood pressure $>140 \mathrm{mmHg}$ or/ and diastolic blood pressure $>100 \mathrm{mmHg}$. Bradycardia was defined as a heart rate $<60$ beats per min and tachycardia as a heart rate $>90$ beats per min.

\section{Data Collection}

Data were collected by a team of expert physicians on a pre-established fact sheet. Demographic data, exposure history, smoking status, pre-existing comorbid conditions, symptoms at presentation and results of clinical examination were also reported.

\section{Statistical Analysis}

Data were entered, checked for errors, and analyzed using SPSS 20 software. Categorical variables were summarized as absolute and relative frequencies. Means and standard deviations were used to describe continuous variables when they were normally distributed. Otherwise, medians and interquartile ranges (IQRs) were used. Statistical analysis of the categorical data was performed using univariate binary logistic regression (Crude Relative risk (CRR); 95\% Confidence Interval $(\mathrm{Cl})$; p). Then, variables associated with hospitalization in the COVID-19 isolation care unit in the univariate analysis $(p<0.05)$, were included in a multivariate model using binary logistic regression (Adjusted Relative risk (ARR); 95\% Cl; p) to determine the independent factors of hospitalization. The final regression model was converted into an applicable score for the prediction of hospitalization in the COVID-19 isolation ward. The regression coefficients were converted to weighted scores assigned to each variable by dividing each regression coefficient by half of the smallest regression coefficient and rounding to the nearest integer $[13,14]$. Then, for each patient, the individual weighted scores corresponding to the predictors were summed to produce an overall weighted score. The hospitalization score in the COVID-19 unit was evaluated by calculating the optimal cutoff values in accordance with the receiver operating characteristic curve (ROC). The discriminatory power of the prediction value was determined by the area under the receiver operating characteristic curve (AUROC). The sensitivity, the specificity, the positive and the negative predictive values (PPV, NPV) were obtained with standard methods and calculated at different cutoff values. A $p$ value lower than 0.05 was considered as statistically significant.

\section{Ethical Considerations}

This study did not involve human beings, intervention or experiments and participation was entirely voluntary. Anonymity and confidentiality were guaranteed and maintained.

\section{RESULTS}

\section{Characteristics of the Study Population}

Of all, 388 patients were enrolled in the study, among whom 224 cases were males (57.7\%), with a sex ratio (Male / Female) of 1.36. The median age of the study population was 37 years (IQR= [28 - 52.5 years $]$ ). Three hundred and nine patients $(79.6 \%)$ were aged between 15 and 60 years. According to residency, 320 patients (83\%) were living in urban areas. A travel history in the last 14 days was noted in 13 patients (3.4\%) and 45 cases (11.6\%) had contact with a relative who had acute respiratory signs. Seventeen patients (4.4\%) were active smokers. The most common comorbidity was chronic respiratory diseases $(n=43 ; 11.1 \%)$. One hundred and seventy-nine patients ( $46.1 \%$ ) had an onset of symptoms seven days or more before the consultation. The most prevalent general sign was headache $(n=155 ; 39.9 \%)$ and the main respiratory symptom was dyspnoea $(n=198 ; 51 \%)$. On clinical examination, 13 patients (3.4\%) had hypotension. In situation of rest, bradycardia and tachycardia were noted in respectively $11(2.8 \%)$ and $156(40.2 \%)$ patients. Twenty-nine patients $(7.5 \%)$ had a respiratory rate $>30$ breaths per min. Oxygen saturation less than $88 \%$ was noted in 11 patients $(2.8 \%)$. One hundred and fifty patients (38.7\%) were hospitalized in the COVID-19 isolation tertiary-care unit (Table 1).

\section{Predictive Factors of Hospitalization in the COVID-19 Isolation Tertiary-Care Unit}

Results of univariate logistic analysis showed that predictive factors of hospitalization in the COVID-19 isolation tertiary-care unit were oxygen saturation $<88 \%$ (CRR=20.44; $\mathrm{p}=0.004)$, bradycardia (CRR $=16.92 ; \mathrm{p}=0.007)$, respiratory wrestling signs ( $C R R=10.68 ; p<0.001$ ), hypotension ( $C R R=9.33$; $\mathrm{p}=0.004)$ and oxygen saturation between 88 and $92 \%$

Table 1. Patients' characteristics

\begin{tabular}{|c|c|c|c|}
\hline \multicolumn{2}{|c|}{ Variables } & $\mathbf{N}$ & $\%$ \\
\hline \multicolumn{4}{|c|}{ Demographic characteristics } \\
\hline \multirow[t]{2}{*}{ Gender } & Men & 224 & 57.7 \\
\hline & Women & 164 & 42.3 \\
\hline \multirow[t]{3}{*}{ Age groups (years) } & $<15$ & 17 & 4.4 \\
\hline & [15-60] & 309 & 79.6 \\
\hline & $\geq 60$ & 62 & 16 \\
\hline \multirow[t]{2}{*}{ Residency } & Urban & 322 & 83 \\
\hline & Rural & 66 & 17 \\
\hline \multicolumn{4}{|l|}{ Exposure history } \\
\hline \multicolumn{2}{|c|}{ Travel history in the last 14 days } & 13 & 3.4 \\
\hline \multicolumn{2}{|c|}{ Contact with a relative who has acute respiratory signs } & 45 & 11.6 \\
\hline \multicolumn{2}{|l|}{ Current smoking } & 17 & 4.4 \\
\hline \multicolumn{4}{|c|}{ Pre-existing comorbid conditions } \\
\hline \multicolumn{2}{|c|}{ Chronic respiratory diseases } & 43 & 11.1 \\
\hline \multicolumn{4}{|c|}{ Cardiovascular diseases } \\
\hline \multicolumn{2}{|c|}{ Chronic hypertension } & 35 & 9 \\
\hline \multicolumn{2}{|c|}{ Ischemic heart diseases } & 32 & 8.2 \\
\hline \multicolumn{2}{|c|}{ Thromboembolic diseases } & 7 & 1.8 \\
\hline \multicolumn{2}{|l|}{ Diabetes } & 33 & 8.5 \\
\hline \multicolumn{2}{|c|}{ Other endocrine disorders } & 15 & 3.9 \\
\hline \multicolumn{2}{|l|}{ Hyperlipemia } & 18 & 4.6 \\
\hline \multicolumn{2}{|l|}{ Chronic renal failure } & 14 & 3.6 \\
\hline \multicolumn{2}{|l|}{ Malignant tumour } & 5 & 1.3 \\
\hline \multicolumn{2}{|c|}{ Having $\geq 2$ comorbidities } & 46 & 11.9 \\
\hline \multicolumn{2}{|l|}{ Surgical history } & 101 & 26 \\
\hline \multicolumn{2}{|l|}{ Allergic history } & 17 & 4.4 \\
\hline \multicolumn{2}{|l|}{ Pregnancy } & 6 & 1.5 \\
\hline
\end{tabular}


Table 1 (continued). Patients' characteristics

\begin{tabular}{|c|c|c|c|}
\hline \multirow{2}{*}{\multicolumn{2}{|c|}{$\begin{array}{l}\text { Variables } \\
\text { Presenting symptoms }\end{array}$}} & $\mathbf{N}$ & $\%$ \\
\hline & & & \\
\hline \multicolumn{2}{|c|}{ Onset $\geq 7$ days before consultation } & 179 & 46.1 \\
\hline \multicolumn{2}{|l|}{ General signs } & & \\
\hline \multicolumn{2}{|l|}{ Headache } & 155 & 39.9 \\
\hline \multicolumn{2}{|l|}{ Arthralgia } & 88 & 22.7 \\
\hline \multicolumn{2}{|l|}{ Myalgia } & 70 & 18 \\
\hline \multirow{2}{*}{\multicolumn{2}{|c|}{$\begin{array}{l}\text { Asthenia } \\
\text { Respiratory symptoms }\end{array}$}} & 16 & 4.1 \\
\hline & & & \\
\hline \multicolumn{2}{|l|}{ Dyspnea } & 198 & 51 \\
\hline \multicolumn{2}{|l|}{ Dry cough } & 193 & 49.7 \\
\hline \multicolumn{2}{|l|}{ Dry throat } & 150 & 38.7 \\
\hline \multicolumn{2}{|l|}{ Productive cough } & 79 & 20.4 \\
\hline \multicolumn{2}{|l|}{ Rhinorrhea } & 64 & 16.5 \\
\hline \multicolumn{2}{|l|}{ Chest pain } & 16 & 4.1 \\
\hline \multicolumn{2}{|c|}{ Respiratory wrestling signs } & 21 & 5.4 \\
\hline \multicolumn{4}{|l|}{ Digestive symptoms } \\
\hline \multicolumn{2}{|l|}{ Diarrhea } & 94 & 24.2 \\
\hline \multicolumn{2}{|l|}{ Nausea or vomit } & 72 & 18.6 \\
\hline \multicolumn{2}{|l|}{ Constipation } & 4 & 1 \\
\hline \multicolumn{2}{|l|}{ Epigastralgia } & 3 & 0.8 \\
\hline \multicolumn{4}{|l|}{ Clinical examination } \\
\hline \multicolumn{2}{|l|}{ Fever $>38.5^{\circ} \mathrm{C}$} & 48 & 12.4 \\
\hline \multirow[t]{2}{*}{$\begin{array}{l}\text { Blood pressure } \\
(\mathrm{mmHg})\end{array}$} & $\begin{array}{l}\text { Hypotension }(\mathrm{SBP}<90 \text { or/ and } \\
\mathrm{DBP}<60 \mathrm{mmHg} \text { ) }\end{array}$ & 13 & 3.4 \\
\hline & $\begin{array}{l}\text { Hypertension }(\mathrm{SBP}>140 \text { or } / \text { and } \\
\mathrm{DBP}>100 \mathrm{mmHg})\end{array}$ & 25 & 6.4 \\
\hline \multirow[t]{2}{*}{ Pulse (beats per min) } & Bradycardia (< 60 beats per min) & 11 & 2.8 \\
\hline & Tachycardia (> 90 beats per $\mathrm{min}$ ) & 156 & 40.2 \\
\hline \multirow{3}{*}{$\begin{array}{l}\text { Respiratory rate } \\
\text { (breaths per min) }\end{array}$} & $<25$ & 336 & 86.6 \\
\hline & {$[25-30]$} & 23 & 5.9 \\
\hline & $>30$ & 29 & 7.5 \\
\hline \multirow[t]{3}{*}{ Oxygen saturation (\%) } & $>92$ & 344 & 88.7 \\
\hline & {$[88-92]$} & 33 & 8.5 \\
\hline & $<88$ & 11 & 2.8 \\
\hline \multicolumn{3}{|c|}{ Hospitalizations in the COVID-19 isolation tertiary-care unit 150} & 38.7 \\
\hline
\end{tabular}

(CRR=9.19; $\quad p<0.001)$. Besides, ischemic heart diseases (CRR=3.91; $\mathrm{p}=0.001$ ), having at least two comorbidities $(C R R=3.46 ; p<0.001)$, dyspnea ( $C R R=3.46 ; p<0.001)$, respiratory rate exceeding 30 cycles per minute ( $C R R=3.42 ; p=0.003$ ), diabetes ( $C R R=3.06 ; p=0.003)$, chronic hypertension $(C R R=2.97$; $p=0.003)$ and chronic respiratory diseases ( $C R R=2.19 ; p=0.016)$ were associated with higher risk of hospitalization. Moreover, coming from rural areas ( $C R R=1.75 ; p=0.039)$, productive cough ( $C R R=1.73 ; p=0.03)$ and an onset of symptoms seven days or more before the consultation ( $C R R=1.60 ; p=0.024$ ) were also predictive factors of hospitalization in the COVID-19 isolation tertiary-care unit. However, dry cough ( $C R R=0.28 ; p<0.001)$, myalgia ( $C R R=0.33 ; p=0.001)$, age between 15 and 60 years (CRR $=0.34 ; p=0.033)$, rhinorrhoea $(C R R=0.42 ; p=0.006)$, dry throat $(C R R=0.42 ; p<0.001)$, headache $(C R R=0.54 ; p=0.006)$ and diarrhea (CRR $=0.56 ; p=0.024)$ were associated with lower risk of hospitalization (Table 2).

Multivariate analysis showed that factors independently associated with admission to COVID-19 isolation tertiary-care unit were oxygen saturation $<88 \%$ (ARR=16.91; $p=0.013$ ), hypotension ( $A R R=11.71 ; p=0.004)$, oxygen saturation between 88 and $92 \%$ ( $A R R=5.90 ; p=0.001)$, respiratory wrestling signs (ARR=4.63; $p=0.042$ ), dyspnea (ARR=3.22; $p<0.001$ ), chronic hypertension $(A R R=2.76 ; p=0.027)$ and ischemic heart diseases (ARR=2.67; $p=0.035$ ) (Table 2).

\section{Risk Scoring System Predictive of Hospitalization in the COVID-19 Isolation Tertiary-Care Unit}

A weighted score was assigned to each factor found to be independently associated with hospitalization in the COVID-19 isolation tertiary-care unit as follows: ischemic heart diseases: 2 points; chronic hypertension: 2 points; dyspnea: 2 points; respiratory wrestling signs: 3 points; oxygen saturation $\leq 92 \%$ :

Table 2. Predictive factors of hospitalisation in the COVID-19 isolation tertiary-care unit: results of univariate and multivariate logistic regression analysis

\begin{tabular}{|c|c|c|c|c|c|}
\hline Variables & & Crude RR [95\% CI] & p value & Adjusted RR [95\% Cl] & p value \\
\hline \multicolumn{6}{|l|}{ Demographic characteristics } \\
\hline \multirow[t]{2}{*}{ Gender } & Men & 1 & & & \\
\hline & Women & $0.97[0.64-1.47]$ & 0.900 & & \\
\hline \multirow[t]{3}{*}{ Age groups (years) } & $<15$ & 1 & $<0.001$ & & \\
\hline & {$[15-60[$} & $0.34[0.12-1.91]$ & 0.033 & & \\
\hline & $\geq 60$ & $1.18[0.39-3.54]$ & 0.75 & & \\
\hline \multirow[t]{2}{*}{ Residency } & Urban & 1 & & & \\
\hline & Rural & $1.75[1.02-2.98]$ & 0.039 & & \\
\hline \multicolumn{6}{|l|}{ Exposure history } \\
\hline \multirow[t]{2}{*}{ Travel history in the last 14 days } & No & 1 & & & \\
\hline & Yes & $0.69[0.21-2.30]$ & 0.554 & & \\
\hline \multirow{2}{*}{$\begin{array}{l}\text { Contact with a relative who has acute } \\
\text { respiratory signs }\end{array}$} & No & 1 & & & \\
\hline & Yes & $0.61[0.31-1.20]$ & 0.155 & & \\
\hline \multirow[t]{2}{*}{ Current smoking } & No & 1 & & & \\
\hline & Yes & $2.35[0.87-6.33]$ & 0.089 & & \\
\hline \multicolumn{6}{|l|}{ Pre-existing comorbid conditions } \\
\hline \multirow[t]{2}{*}{ Chronic respiratory diseases } & No & 1 & & 1 & \\
\hline & Yes & $2.19[1.15-4.16]$ & 0.016 & $1.78[0.81-3.92]$ & 0.151 \\
\hline \multicolumn{6}{|l|}{ Cardiovascular diseases } \\
\hline \multirow[t]{2}{*}{ Chronic hypertension } & No & 1 & & 1 & \\
\hline & Yes & $2.97[1.44-6.10]$ & 0.003 & $2.76[1.12-6.81]$ & 0.027 \\
\hline \multirow[t]{2}{*}{ Ischemic heart diseases } & No & 1 & & 1 & \\
\hline & Yes & $3.91[1.80-8.53]$ & 0.001 & $2.67[1.07-6.65]$ & 0.035 \\
\hline \multirow[t]{2}{*}{ Thromboembolic diseases } & No & 1 & & & \\
\hline & Yes & $2.14[0.47-9.72]$ & 0.322 & & \\
\hline \multirow[t]{2}{*}{ Diabetes } & No & 1 & & & \\
\hline & Yes & $3.06[1.46-6.43]$ & 0.003 & & \\
\hline \multirow[t]{2}{*}{ Other endocrine disorders } & No & 1 & & & \\
\hline & Yes & $2.46[0.86-7.08]$ & 0.093 & & \\
\hline
\end{tabular}


Table 2 (continued). Predictive factors of hospitalisation in the COVID-19 isolation tertiary-care unit: results of univariate and multivariate logistic regression analysis

\begin{tabular}{|c|c|c|c|c|c|c|}
\hline \multicolumn{3}{|c|}{ Variables } & Crude RR $[95 \% \mathrm{Cl}]$ & p value & Adjusted RR [95\% Cl] & p value \\
\hline \multicolumn{7}{|c|}{ Pre-existing comorbid conditions } \\
\hline \multirow{2}{*}{\multicolumn{2}{|c|}{ Hyperlipemia }} & No & 1 & & & \\
\hline & & $\overline{Y e s}$ & $2.05[0.79-5.32]$ & 0.139 & & \\
\hline \multirow{2}{*}{\multicolumn{2}{|c|}{ Chronic renal failure }} & No & 1 & & & \\
\hline & & $\overline{Y e s}$ & $1.61[0.55-4.70]$ & 0.379 & & \\
\hline \multirow{2}{*}{\multicolumn{2}{|c|}{ Malignant tumour }} & No & 1 & & & \\
\hline & & $\overline{Y e s}$ & $1.05[0.17-6.41]$ & 0.951 & & \\
\hline \multirow{2}{*}{\multicolumn{2}{|c|}{ Having $\geq 2$ comorbidities }} & No & 1 & & & \\
\hline & & Yes & $3.46[1.81-6.61]$ & $<0.001$ & & \\
\hline \multirow{2}{*}{\multicolumn{2}{|c|}{ Surgical history }} & No & 1 & & & \\
\hline & & Yes & $1.31[0.83-2.08]$ & 0.240 & & \\
\hline \multirow{2}{*}{\multicolumn{2}{|c|}{ Allergic history }} & No & 1 & & & \\
\hline & & Yes & $0.47[0.15-1.48]$ & 0.199 & & \\
\hline \multirow{2}{*}{\multicolumn{2}{|c|}{ Pregnancy }} & No & 1 & & & \\
\hline & & Yes & $0.79[0.14-4.37]$ & 0.788 & & \\
\hline \multicolumn{7}{|l|}{ Presenting symptoms } \\
\hline \multirow{2}{*}{\multicolumn{2}{|c|}{ Onset $\geq 7$ days before consultation }} & No & 1 & & & \\
\hline & & Yes & $1.60[1.06-2.42]$ & 0.024 & & \\
\hline General signs & & & & & & \\
\hline Headache & & No & 1 & & & \\
\hline & & Yes & $0.54[0.35-0.84]$ & 0.006 & & \\
\hline Arthralgia & & No & 1 & & & \\
\hline & & Yes & $0.68[0.41-1.12]$ & 0.134 & & \\
\hline Myalgia & & No & 1 & & & \\
\hline & & Yes & $0.33[0.17-0.62]$ & 0.001 & & \\
\hline Asthenia & & No & 1 & & & \\
\hline & & Yes & $0.51[0.16-1.63]$ & 0.252 & & \\
\hline Respiratory symptoms & & & & & & \\
\hline Dyspnea & & No & 1 & & 1 & \\
\hline & & Yes & $3.46[2.24-5.34]$ & $<0.001$ & $3.22[1.92-5.39]$ & $<0.001$ \\
\hline Dry cough & & No & 1 & & & \\
\hline & & Yes & $0.28[0.18-0.44]$ & $<0.001$ & & \\
\hline Dry throat & & No & 1 & & & \\
\hline & & Yes & $0.42[0.27-0.65]$ & $<0.001$ & & \\
\hline Productive cough & & No & 1 & & & \\
\hline & & Yes & $1.73[1.05-2.86]$ & 0.030 & & \\
\hline Rhinorrhea & & No & 1 & & & \\
\hline & & $\overline{Y e s}$ & $0.42[0.23-0.79]$ & 0.006 & & \\
\hline Chest pain & & No & 1 & & & \\
\hline & & Yes & $2.76[0.98-7.76]$ & 0.054 & & \\
\hline Respiratory wrestling & signs & No & 1 & & 1 & \\
\hline & & Yes & $10.68[3.08-36.93]$ & $<0.001$ & $4.63[1.05-20.24]$ & 0.042 \\
\hline Digestive symptoms & & & & & & \\
\hline Diarrhea & & No & 1 & & & \\
\hline & & $\overline{Y e s}$ & $0.56[0.33-0.92]$ & 0.024 & & \\
\hline Nausea or vomit & & No & 1 & & & \\
\hline & & Yes & $0.87[0.51-1.48]$ & 0.623 & & \\
\hline Constipation & & No & 1 & & & \\
\hline & & Yes & $1.59[0.22-11.44]$ & 0.643 & & \\
\hline Epigastralgia & & No & 1 & & & \\
\hline & & Yes & $3.20[0.28-35.63]$ & 0.344 & & \\
\hline Clinical examination & & & & & & \\
\hline Fever $>38.5^{\circ} \mathrm{C}$ & & No & 1 & & & \\
\hline & & $\overline{Y e s}$ & $0.69[0.36-1.31]$ & 0.262 & & \\
\hline Blood pressure & Hypotension $(\mathrm{SBP}<90$ or/ & No & 1 & & 1 & \\
\hline$(\mathrm{mmHg})$ & and $\mathrm{DBP}<60 \mathrm{mmHg}$ ) & $\overline{Y e s}$ & $9.33[2.04-42.74]$ & 0.004 & $11.71[2.21-61.87]$ & 0.004 \\
\hline & $\begin{array}{ll}\text { Hypertension } & (\mathrm{SBP}>140\end{array}$ & No & 1 & & & \\
\hline & or/ and DBP>100 mmHg) & Yes & $1.50[0.66-3.39]$ & 0.324 & & \\
\hline Pulse (beats per min) & Bradycardia & No & 1 & & & \\
\hline & (<60 beats per $\min$ ) & Yes & $16.92[2.14-133.64]$ & 0.007 & & \\
\hline & Tachycardia & No & 1 & & & \\
\hline & ( $>90$ beats per $\mathrm{min}$ ) & $\overline{Y e s}$ & $0.94[0.62-1.43]$ & 0.781 & & \\
\hline Respiratory rate & & $<25$ & 1 & 0.007 & & \\
\hline (breaths per min) & & [25-30] & $1.65[0.70-3.85]$ & 0.247 & & \\
\hline & & $>30$ & $3.42[1.54-7.59]$ & 0.003 & & \\
\hline Oxygen saturation (\%) & & $>92$ & 1 & $<0.001$ & 1 & $<0.001$ \\
\hline & & $\begin{array}{l}88-92] \\
\end{array}$ & $9.19[3.69-22.91]$ & $<0.001$ & $5.90[2.10-16.55]$ & 0.001 \\
\hline & & $<88$ & $20.44[2.58-161.66]$ & 0.004 & $16.91[1.79-159.06]$ & 0.013 \\
\hline
\end{tabular}


Table 3. Weighted scores corresponding to predictive factors of hospitalization in the COVID-19 isolation tertiary-care unit

\begin{tabular}{lcc}
\hline Variables & Adjusted RR [95\% CI] & Regression Coefficient \\
\hline Ischemic heart diseases & $2.67[1.07-6.65]$ & 0.98 \\
\hline Chronic hypertension & $2.76[1.12-6.81]$ & 1.01 \\
\hline Dyspnea & $3.22[1.92-5.39]$ & 1.17 \\
\hline Respiratory wrestling signs & $4.63[1.05-20.24]$ & 1.53 \\
\hline Oxygen saturation $\leq 92 \%$ & $5.90[2.10-16.55]$ & 1.77 \\
\hline Hypotension & $11.71[2.21-61.87]$ & 2 \\
\hline
\end{tabular}

RR: Relative risk; Cl: Confidence interval

Table 4. The sensitivity, specificity and predictive values of the weighted score predictive of hospitalization in the covid-19 isolation tertiary-care unit at various cutoff points

\begin{tabular}{|c|c|c|c|c|}
\hline Cutoff Points & Sensitivity (\%) & Specificity (\%) & PPV (\%) & NPV (\%) \\
\hline$\geq 2$ & 87.7 & 53.8 & 53 & 83.1 \\
\hline$\geq 3$ & 44 & 92.9 & 79.5 & 72.5 \\
\hline$\geq 4$ & 42.7 & 92.9 & 79 & 72 \\
\hline$\geq 5$ & 31.3 & 96.2 & 83.9 & 69 \\
\hline$\geq 6$ & 22.7 & 97.5 & 85 & 66 \\
\hline$\geq 7$ & 12 & 98.3 & 81.8 & 63.9 \\
\hline$\geq 8$ & 8.7 & 98.7 & 81.3 & 63.2 \\
\hline$\geq 9$ & 4.7 & 99.6 & 87.5 & 62.4 \\
\hline$\geq 10$ & 2.7 & 100 & 100 & 62 \\
\hline
\end{tabular}

4 points; hypotension: 5 points (Table 3 ). The individual scores were added together to produce an overall weighted score ranging from 0 to 18 points. In our study, the median score value was 2 , with extremes of 0 and 14 . The AUROC of this score was 0.75 ([95\% Cl: $0.70,0.80] ; p<0.001)$. At a cut-off point $\geq 2$, the scoring system had a sensitivity of $82.7 \%$ and a specificity of $53.8 \%$. This cut-off level was associated with a PPV and NPV of $53 \%$ and $83.1 \%$ respectively. At a cut-off point $\geq 3$ the sensitivity was $44 \%$ and the specificity was $92.9 \%$ with a PPV of $79.5 \%$ and an NPV of $72.5 \%$. At a cut-off point $\geq 10$, the specificity and the PPV achieved 100\% (Table 4).

\section{DISCUSSION}

The COVID-19 pandemic continues to be a global health crisis. The number of suspected patients and positive cases has increased exponentially in many countries. In Tunisia, hospitalizations associated with COVID-19 have created significant challenges in the allocation of human and infrastructural resources for public health facilities, that are already facing financial constraints, especially in rural areas [15]. The present study indicated that the prevalence of hospitalization of COVID-19 suspected patients, in the COVID19 isolation tertiary-care unit in Sfax, was 38.7\% between March and June 2020. A survey conducted in New York City revealed that the prevalence of hospitalization of COVID-19infected patients was $27 \%$ as of April 12, 2020 [16]. Another study in Michigan of 463 patients with COVID-19 reported a hospitalization prevalence of $76.7 \%$, from March 9 to March 27 , 2020 [17]. The overwhelming influx of patients with COVID-19 to many hospitals presents a need to timely identify patients who require hospitalization. Therefore, it is important to determine factors that stratify patients at risk of requiring hospitalization.

In the current study, an oxygen saturation $\leq 92 \%$, respiratory wrestling signs and dyspnea were independent predictive factors for hospital admission. Our results were largely in line with other surveys that reported that hypoxemia and dyspnoea were independently associated with worse clinical outcomes $[18,19]$. Indeed, a study of 463 patients with COVID-19 indicated that patients requiring hospital admission had dyspnoea and lowest oxygen saturation [17]. Another study of 140 patients with COVID-19 found that patients with oxygen saturation $>90.5 \%$ were more likely to survive while dyspnoea was independently associated with mortality [18]. Likewise, a study of 5279 patients with COVID-19 reported that an oxygen saturation $<88 \%$ and an oxygen saturation between 88 and $92 \%$ were among predictive factors most strongly associated with critical illness with adjusted odds ratios of 3.67 and 1.49 respectively [20]. However, in this study, chronic respiratory diseases did not feature among independent predictive factors of admission in the COVID-19 units. This was consistent with previous studies that did not report a significant association between pre-existing chronic respiratory diseases and hospital admission of COVID-19 patients [17] or the COVID-19 severity [3,21]. There is no epidemiological or pathophysiological explanation for the absence of chronic respiratory diseases as risk factor of illness severity among COVID-19 patients [20].

On the other hand, the current study confirmed that preexisting cardiovascular diseases such as chronic hypertension and ischemic heart diseases were independent predictive factors of admission in the COVID-19 isolation tertiary care units. Our findings support the observations of earlier studies, which found a high percentage of hospitalized patients with pre-existing cardiovascular diseases. Indeed, it has been reported that heart failure and hypertension were independent risk factors of hospital admission among COVID19 patients [20]. It has been also reported that coronary heart disease was an independent risk factor associated with inhospital death for COVID-19 patients [3]. Besides, other studies found that patients with cardiovascular diseases were more likely to develop severe forms of COVID-19 [22,23]. In fact, the angiotensin-converting enzyme 2 (ACE2) has a vital role in the regulation of heart function and the development of hypertension [24]. In addition, ACE2 has been shown to also serve as a functional receptor for coronaviruses [25], including SARS-CoV-2. Indeed, the binding of the spike protein of the virus to ACE2 triggers infection by SARS-CoV-2 [25]. Since ACE2 is highly expressed in the heart and lungs [25], symptoms of COVID-19 are more severe in patients with cardiovascular diseases. 
The present study also revealed that hypotension was independently associated with admission in the COVID-19 isolation tertiary care units with an ARR of 11.71 . Nonetheless, other studies have not noted a significant association between hypotension and COVID-19 severity $[3,7]$.

An interesting finding in this study was the weighted score model based on simple information available at the COVID-19 sorting box. This tool might potentially guide physicians in the management of COVID-19 suspected patients and will assist them to timely identify patients at highest risk of hospitalization.

Other tools have been performed in previous studies and various scoring systems have been created for prediction of the disease severity in COVID-19. A study conducted in China attempted to evaluate the disease severity in COVID-19 on the basis of a scoring system that included age, white blood cell count, neutrophil, glomerular filtration rate and myoglobin [26]. According to this scoring system, the probability of patients in high-risk group developing severe disease in COVID19 was 20 times than that in low-risk group with a sensitivity of prediction of $70.8 \%$ and a specificity of $89.3 \%$. Another study conducted in China proposed a lymphocyte percentage-time model to predict disease severity in COVID-19 [27]. Besides, a study conducted in United Kingdom suggested a clinical risk score to predict the risk of death or critical care admission in hospitalized COVID-19 patients, including age $>40$, male, nonwhite ethnicity, oxygen saturations $<93 \%$, radiological severity score $>3$, neutrophil count $>8.010^{9} / \mathrm{L}, \mathrm{CRP}>40 \mathrm{mg} / \mathrm{L}$, albumin $<34 \mathrm{~g} / \mathrm{L}$, creatinine $>100 \mu \mathrm{mol} / \mathrm{L}$, diabetes mellitus, hypertension and chronic lung disease [28]. Compared with other previous scoring systems, our scoring system was relatively a good predictor of COVID-19 hospital admission, and its performance depended on the cut-off value. Indeed, our score had an AUROC of 0.75 , indicating good predictive power in discriminating hospitalization in the COVID-19 isolation tertiary-care unit. When high risk was defined as an overall score of $\geq 2$, the scoring system had a good screening performance with a good sensitivity $(82.7 \%)$. When the cut-off was raised to 3 , the sensitivity dropped (44\%) and the specificity increased appreciably indicating that $92.9 \%$ of patients with mild to none COVID-19 was ruled out.

\section{CONCLUSION}

Given the rapid increase in the number of COVID-19 patients worldwide, while no specialized treatment is yet available, the early identification of patients who require admission is essential for timely intervention. Our scoring system included ischemic heart diseases, chronic hypertension, dyspnoea, respiratory wrestling signs, oxygen saturation $\leq 92 \%$ and hypotension. This risk score will allow patient stratification and will guide hospitalization decisions for suspected COVID-19 patients in order to facilitate their clinical management while appropriately allocating limited human and hospital resources.

Author contributions: All authors have sufficiently contributed to the study, and agreed with the results and conclusions.

Funding: No funding source is reported for this study.

Declaration of interest: No conflict of interest is declared by authors.

\section{REFERENCES}

1. Esakandari H, Nabi-Afjadi M, Fakkari-Afjadi J, et al. A comprehensive review of COVID-19 characteristics. Biol Proced Online. 2020;22:19. https://doi.org/10.1186/ s12575-020-00128-2 PMid:32774178 PMCid:PMC7402395

2. Coronaviridae Study Group of the International Committee on Taxonomy of Viruses. The species severe acute respiratory syndrome-related coronavirus: classifying 2019-nCoV and naming it SARS-CoV-2. Nat Microbiol. 2020;5:536-44. https://doi.org/10.1038/s41564-020-0695-z PMid:32123347 PMCid:PMC7095448

3. Zhou F, Yu T, Du R, et al. Clinical course and risk factors for mortality of adult inpatients with COVID-19 in Wuhan, China: a retrospective cohort study. Lancet. 2020;395:105462. https://doi.org/10.1016/S0140-6736(20)30566-3

4. Rothan HA, Byrareddy SN. The epidemiology and pathogenesis of coronavirus disease (COVID-19) outbreak. J Autoimmun. 2020;109:102433. https://doi.org/10.1016/ j.jaut.2020.102433 PMid:32113704 PMCid:PMC7127067

5. Vabret A, Dina J, Brison E, et al. Coronavirus humains (HCoV). Pathol Biol (Paris). 2009;57:149-60. https://doi.org/ 10.1016/j.patbio.2008.02.018 PMid:18456429 PMCid: PMC7125620

6. Chen N, Zhou M, Dong X, et al. Epidemiological and clinical characteristics of 99 cases of 2019 novel coronavirus pneumonia in Wuhan, China: a descriptive study. Lancet. 2020;395:507-13. https://doi.org/10.1016/S0140-6736(20) 30211-7

7. Wang D, Hu B, Hu C, et al. Clinical Characteristics of 138 Hospitalized Patients With 2019 Novel CoronavirusInfected Pneumonia in Wuhan, China. JAMA. 2020;323:1061-9. https://doi.org/10.1001/jama.2020.1585 PMid:32031570 PMCid:PMC7042881

8. Louhaichi S, Allouche A, Baili H, et al. Features of patients with 2019 novel coronavirus admitted in a pneumology department: The first retrospective Tunisian case series. Tunis Med. 2020;98:261-5.

9. Fredj HB, Chérif F. Novel Corona virus disease infection in Tunisia: Mathematical model and the impact of the quarantine strategy. Chaos Solitons Fractals. 2020;138:109969. https://doi.org/10.1016/j.chaos.2020. 109969 PMid:32536761 PMCid:PMC7284269

10. Chaari L, Golubnitschaja O. Covid-19 pandemic by the "real-time" monitoring: the Tunisian case and lessons for global epidemics in the context of 3PM strategies. EPMA J. 2020;1-6. https://doi.org/10.1007/s13167-020-00207-0 PMid:32341719 PMCid:PMC7182506

11. de Simone G, Mancusi C. COVID-19: Timing is Important. Eur J Intern Med. 2020;77:134-5. https://doi.org/10.1016/ j.ejim.2020.04.019 PMid:32362362 PMCid:PMC7152892

12. Instance Nationale de l'Évaluation et de l'Accréditation en Santé. Guide parcours du patient suspect ou confirmé COVID-19. Available at http://www.ineas.tn/sites/default/ files//gps_covid-19.pdf (Accessed: 17 October 2020).

13. Ben Ayed H, Koubaa M, Hammami F, et al. Performance of an easy and simple new scoring model in predicting multidrug-resistant enterobacteriaceae in communityacquired urinary tract infections. Open Forum Infect Dis. 2019;6. https://doi.org/10.1093/ofid/ofz103 PMid:30949542 PMCid:PMC6441566 
14. Sullivan LM, Massaro JM, D’Agostino RB. Presentation of multivariate data for clinical use: The Framingham Study risk score functions. Stat Med. 2004;23:1631-60. https://doi.org/10.1002/sim.1742 PMid:15122742

15. Saidi A, Hamdaoui M. On measuring and decomposing inequality of opportunity in access to health services among Tunisian children: a new approach for public policy. Health Qual Life Outcomes. 2017;15:213. https://doi.org/ 10.1186/s12955-017-0777-7 PMid:29070047 PMCid: PMC5655845

16. Chilimuri S, Sun H, Alemam A, et al. Predictors of mortality in adults admitted with COVID-19: Retrospective cohort study from New York City. West J Emerg Med. 2020;21:77984. https://doi.org/10.5811/westjem.2020.6.47919 PMid: 32726241 PMCid:PMC7390589

17. Suleyman G, Fadel RA, Malette KM, et al. Clinical Characteristics and morbidity associated with coronavirus disease 2019 in a series of patients in Metropolitan Detroit. JAMA Netw Open. 2020;3:e2012270. https://doi.org/ 10.1001/jamanetworkopen.2020.12270 PMid:32543702 PMCid:PMC7298606

18. Xie J, Covassin N, Fan Z, et al. Association between hypoxemia and mortality in patients with COVID-19. Mayo Clin Proc. 2020;95:1138-47. https://doi.org/10.1016/ j.mayocp.2020.04.006 PMid:32376101 PMCid:PMC7151468

19. Duan J, Wang $X$, Chi J, et al. Correlation between the variables collected at admission and progression to severe cases during hospitalization among patients with COVID-19 in Chongqing. J Med Virol. 2020. https://doi.org/10.1002/ jmv.26082 PMid:32470186 PMCid:PMC7283752

20. Petrilli CM, Jones SA, Yang J, et al. Factors associated with hospital admission and critical illness among 5279 people with coronavirus disease 2019 in New York City: prospective cohort study. BMJ. 2020;369:m1966. https://doi.org/10.1136/bmj.m1966 PMid:32444366 PMCid: PMC7243801
21. Halpin DMG, Faner R, Sibila O, et al. Do chronic respiratory diseases or their treatment affect the risk of SARS-CoV-2 infection?. Lancet Respir Med. 2020;8:436-8. https://doi.org/10.1016/S2213-2600(20)30167-3

22. Du R-H, Liang L-R, Yang C-Q, et al. Predictors of mortality for patients with COVID-19 pneumonia caused by SARSCoV-2: a prospective cohort study. Eur Respir J. 2020;55:2000524. https://doi.org/10.1183/13993003.005242020 PMid:32269088 PMCid:PMC7144257

23. Li X, Xu S, Yu M, et al. Risk factors for severity and mortality in adult COVID-19 inpatients in Wuhan. J Allergy Clin Immunol. 2020;146:110-8. https://doi.org/10.1016/ j.jaci.2020.04.006 PMid:32294485 PMCid:PMC7152876

24. Zheng Y-Y, Ma Y-T, Zhang J-Y, et al. COVID-19 and the cardiovascular system. Nat Rev Cardiol. 2020;1-2. https://doi.org/10.1038/s41569-020-0360-5 PMid:32139904 PMCid:PMC7095524

25. Turner AJ, Hiscox JA, Hooper NM. ACE2: from vasopeptidase to SARS virus receptor. Trends Pharmacol Sci. 2004;25:291-4. https://doi.org/10.1016/j.tips.2004.04. 001 PMid:15165741 PMCid:PMC7119032

26. Zhang C, Qin L, Li K, et al. A Novel Scoring System for Prediction of Disease Severity in COVID-19. Front Cell Infect Microbiol. 2020;10:318. https://doi.org/10.3389/fcimb.2020 .00318 PMid:32582575 PMCid:PMC7292148

27. Tan L, Wang Q, Zhang D, et al. Lymphopenia predicts disease severity of COVID-19: a descriptive and predictive study. Signal Transduct Target Ther. 2020;5:61. https://doi.org/10.1038/s41392-020-0159-1

28. Galloway JB, Norton S, Barker RD, et al. A clinical risk score to identify patients with COVID-19 at high risk of critical care admission or death: An observational cohort study. J Infect. 2020;81:282-8. https://doi.org/10.1016/j.jinf.2020. 05.064 PMid:32479771 PMCid:PMC7258846 